\title{
Závislost Ruska na př́jmech $z$ těžby ropy a zemního plynu
}

\section{Markéta Vondřichová}

\author{
Vedoucí práce: Ing. Zuzana Stuchlíková
}

\section{Úvod}

Dobám centrálně plánovaného hospodářství odzvonilo, na scénu nastoupilo tržní hospodářství a s ním nová éra tzv. Nových Rusů, oligarchů, kteří nemálo vydělali na privatizaci tehdejšího státního majetku. Rusko se vymanilo ze své nelogické snahy pěstovat kukuřici a obilí na neúrodných, a pro jiná odvětví prospěšných, polích. Zato však začalo hrát prim ve vývozu a obchodu s energetickými surovinami, zejména s ropou a zemním plynem. Ruská federace má největší zásoby zemního plynu na světě a zároveň drží prvenství v jeho těžbě. Co se týče ropy, je v její těžbě na místě druhém a v celosvětových zásobách na místě osmém. ${ }^{1}$ Ruská ekonomika není tou nejdynamičtější na světě, tu mají bezesporu Spojené státy, ale už dávno nemůžeme mluvit o zruinované ekonomice pod vedením ruských diktátorů. Zaznamenává růst a to zejména díky těžbě energetických surovin a jejich následnému vývozu, celých sedmdesát procent proudí za vysokou cenu za barel z Ruska ven. Když k tomu přičteme dotovanou cenu pro ruské obyvatele a nedostatečnou diverzifikaci ekonomiky, dostaneme jednoduchou rovnici, na pravé straně s faktem, že se Ruská federace stává stále více závislá na př́ijmech z exportu a těžby z fosilních paliv.

V současné době globalizace hovoříme o stále se zhoršujícím stavu celého světa, stále ještě nemáme dostatek obnovitelných zdrojů, jakými jsou kupř́ikladu vodní elektrárny, které ale vyprodukují jen okolo $19 \%$ z celkové elektrické ruské produkce. ${ }^{2}$ Na světové úrovni to je necelých $14 \%$, ale to se bude stále zvyšovat, což může znamenat reálnou hrozbu pro Rusko, že jeho nynější dovozci ropy budou více samostatní a méně závislí na Rusku. Náklady na obnovitelné zdroje se od jejich objevení markantně snížily, jsou víceméně jednorázové a to při samém začátku, například postavení vodní elektrárny na přehradě. Dalším důvodem, proč není úplně adekvátní nechat ruskou závislost na př́íjmech z těžby z fosilních paliv bez povšimnutí, je dosažení ropného vrcholu, o kterém se hojně diskutuje a i v této práci se jím budeme na závěr zabývat.

Cílem této seminární práce je analýza současného stavu ruské ekonomiky - především její závislosti na př́ijmech z těžby energetických surovin, jejího postavení a stability ve světové ekonomice.

Práce je rozdělena do 3 částí. V první části je stručně zhodnocen současný stav ruské ekonomiky - zejména její závislost na těžbě energetických surovin. Část druhá rozebírá postoje prezidenta Putina a jeho reformy pro omezení závislosti na těžbě ropy a zemního plynu a celkové strukturální slabosti ekonomiky. Poslední kapitola nastiňuje často diskuto-

1 Country Analysis Brief - Russia, Energy information Administration. Dostupné z http://www.eia.doe.gov/emeu/ cabs/Russia/Background.html.

2 Viz Př́lohy, Tab. č. 3. 
vaný problém ropného vrcholu, jeho př́padné dopady pro Rusko a možnosti využití a hledání nových a alternativních zdrojů.

\section{Závislost ruské ekonomiky na produkci ropy a zemního plynu}

\subsection{Těžba fosilních paliv a růst ruské ekonomiky}

V první části této práce se podíváme na ruskou ekonomiku, její postavení, stabilitu a závislost na př́ijmech z těžby fosilních paliv. Ruská ekonomika má zaručeno až 70 \% státních př́ijmů právě díky jejich exportu. ${ }^{3}$ Cena ropy se od přelomu devatenáctého a dvacátého století, kdy se začala těžit, stále zvyšovala, přičemž významnějším tempem v období první světové války a pak ještě markantněji v letech šedesátých. ${ }^{4}$ Rostoucí cena ropy byla zapř́íčiněna zvyšující se poptávkou, jak se společnost stále více industrializovala. V důsledku značných ruských zásob této suroviny rostl i objem jejich státních př́jmů. Na následujícím grafu můžeme vidět určitou závislost mezi růstem těžby ropy a př́ijmů do státní kasy.

\section{Graf č. 1: Růst reálného HDP a cen ropy, 1997-2004 v \% a USD/barel}

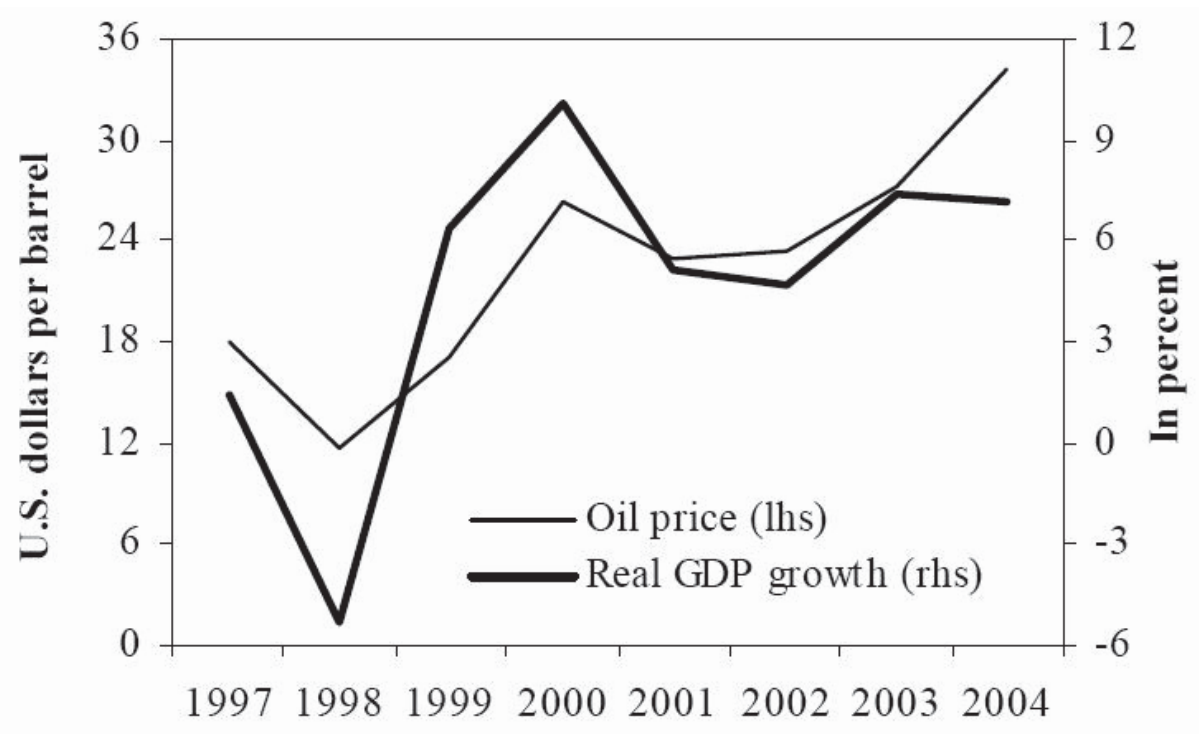

Zdroj: Antonio Spilimbergo, Measuring the performance of fscal policy in Russia, Working paper 05/241. Dostupné z http://www.imf.org/external/pubs/ft/wp/2005/wp05241.pdf.

Můžeme vidět, že se ruská ekonomika zotavila po krizi z roku 1998 a jedním z faktorů byla bezesporu zvyšující se cena ropy. Vidíme právě v roce 1998 její markantní pokles a následný růst. Antonio Spilimbergo uvedl ve své studii, že zvýšení o jeden dolar na barel ropy z Uralu by zvýšilo státní prŕíjmy o 0,35 \% HDP, což je cca 1,8 miliard pro rok $2003 .{ }^{5}$ Ruská ekonomika velmi dynamicky.. Tempo růstu reálného HDP v roce 2001 bylo 5,1 \% oproti $6,4 \% \mathrm{v}$ roce 2005 . V důsledku vysokých cen exportního ruského zboží dosáhla rekordních čísel i platební bilance s přebytkem 86,6 mld. USD. Rusko tak udržuje platební bilanci aktivní. Pro údaje z roku 2005, státní rozpočet pracoval s přebytkem 57 mld. USD

3 Country Analysis Brief - Russia, Energy information Administration. Dostupné z http://www.eia.doe.gov/emeu/ cabs/Russia/Background.html

4 Lomborg, B.: Skeptický ekolog, str.153.

5 Lomborg, B.: Skeptický ekolog, str.153. 
při rozpočtových př́ijmech ve výši 181 mld. USD a výdajích 124 . mld USD. ${ }^{6}$ Vnější stabilitu Ruska potvrzují i údaje o růstu zlatých a měnových rezerv, které dosáhly výše 100,1 mld. USD (nárůst o 23,2 mld., tj. 30 \%). ${ }^{7}$ Všechna tato čísla poukazují na úspěchy rostoucí ruské ekonomiky, ale je potřeba vidět i druhou stránku věci. V př́loze naleznete tabulku vybraných ekonomických indikátorů pro rok 2001 až 2005. Odvážím se říci, že nebýt vysokých objemů exportu ropy a zemního plynu, stejně jako jejich rostoucích cen, čísla by byla odlišná a pravděpodobně ne tak pozitivní. Všechna tato optimistická měření je potřeba konfrontovat nejenom s touto skutečností, ale s řadou dalších problémů ruské ekonomiky.. Patří mezi ně nerovnoměrný rozvoj regionů, nekvalitní infrastruktura a v důsledku toho zoufalá potřeba nového př́livu investic, a pokles populace, který se odhaduje na $17 \%$ do roku $2050 .^{8}$

\subsection{Státní a tržní podniky}

I když doba centrálně plánovaného hospodářství už pominula, přeci jen velice snadno nalezneme její pozůstatky. Je to skutečnost, že ruskému trhu s energetickými zdroji dominují firmy pod státní kontrolou. Společnost Transněft byla státem založena a má výhradní monopol na ropovodní systém v Rusku. Jak moc je její role důležitá je zřejmé z faktu, že 4 ze 7 mil. barelu, které Rusko vyprodukuje na export za den, proteče ropovody. ${ }^{9}$ Obdobně to je v oblasti zemního plynu. Druhou největší světovou společností, po British Petroleum, je ruský Gazprom a ten je vlastněn státem z 50,002 \%. Pro srovnání, největší soukromá ropná společnost Lukoil produkuje okolo 18 \% z celkové ruské produkce. ${ }^{10}$

\subsection{Ropovodní a plynovodní systémy}

To, že Rusko je závislé na exportu ropy a zemního plynu je žrejmé z pohledu na rozsáhlé ruské ropovodní a plynovodní sítě. ${ }^{11}$ Jedním z nejhlavnějších ropovodů je Baltic Pipeline Systém, který vede ze západní Sibiře k Finskému zálivu, což Rusku umožňuje př́stup k severním evropským trhům a méně závislosti na transitních zemích, jako je Litva, Lotyšsko a Estonsko. Tímto ropovodem proteče denně 1,3 mil. barelů ropy. Dalším významným ropovodem je Družba, která vede ze Samary přes běloruský Mozyr, kde se rozdvojuje na severní a jižní větev. Severní větev mírí do Polska a Německa a ta Jižní na Ukrajinu, Mad'arsko, Slovensko a do České republiky. Co se týče plynovodních systémů, jedním z nejznámějších je Soyuz a Yamal - Europe, který spojuje naleziště zemního plynu na ruském poloostrově Yamal na Sibiři s Německem. Nejvíce ropy a zemního plynu vyveze přirozeně Saudská Arábie, ale Rusko je hned na druhém místě.

Rusko je sice závislé na př́ijmech z těžby, ale státy dovážející ropu jsou závislé na Rusku. Prozatím, kdy se nenašel ještě dostatek alternativních zdrojů pro získání energetických surovin, si Rusko nemůže dovolit ukázat nejistotu a strach nad tím, co přijde, až dojde k ropnému vrcholu. Ale abychom Rusku nekřivdili, do určité míry si je vědomo nedostatečné stability svých př́ijmů. Proto prezident Putin zahájil rozsáhlou škálu reforem, ke kterým se dostáváme $\mathrm{v}$ druhé části této práce.

6 Teritoriální informace - Rusko 2007, str. 33. Dostupné z www.businessinfo.cz.

7 Teritoriální informace - Rusko 2007, str. 33. Dostupné z www.businessinfo.cz.

8 Teritoriální informace - Rusko 2007, str. 37.

9 Country Analysis Brief - Russia, Energy information Administration. Dostupné z http://www.eia.doe.gov/emeu/ cabs/Russia/Background.html.

10 Tamtéž.

11 Viz př́lohy Obrázek 1.

12 Viz př́lohy Obrázek 2. 


\section{Postoje prezidenta Putina a jeho reformy jako krok ke snížení závislosti státních př́íjmů na těžbě fosilních paliv}

\subsection{Postoje prezidenta Putina}

Když ruský prezident nastoupil do svého úřadu, v sankpětěrburském Těžebním institutu obhájil disertaci nazvanou „K ruské nadnárodní energetické společnosti““ a představil svou tezi, že „Rusko musí použít své rozsáhlé energetické rezervy k získání geostrategické výhody“، ${ }^{13} \mathrm{Na}$ zasedání Rady národní bezpečnosti z 22. prosince 2005 to vyjádřil následujícími slovy:,Rusko nemůže vládnout v žádné jiné oblasti (než v oblasti energie)." ${ }^{14} \mathrm{Z}$ toho jsou zjevné postoje prezidenta Putina, snaží se vytěžit co nejvíce z postavení své země. Že to mnohdy činí jako pravý ruský car", je otázka jiná a spíše politická. Vra me se tedy do oblasti ekonomické.

Po nástupu Putina v roce 2000 stát nashromáždil působivé finanční prostředky a splatil značnou část ruského zahraničního dluhu. Gazprom předběhl British Petroleum a stal se druhou největší energetickou společností na světě. ${ }^{15}$ Putin přebírá kontrolu stále nad větší částí evropského trhu s plynem a ropou a stejně tak i v Japonsku. Je si vědom, že potřebuje mohutné kapitálové investice, aby udržel produkci uhlovodíků, které se získávají při rafinaci ropy, a Evropa a Japonsko tyto uhlovodíky potřebují a mají peníze na investice. Ano, prohlubuje se tím vzájemná závislost, ale o tom je dnes už nevyhnutelná globalizace a Rusko si tak může zajistit př́ípadnou výhodnou pozici při budoucí spolupráci v oblasti energie, i pokud by se využívaly jiné technologie než dnes. I tato skutečnost může fungovat jako čin pro snižování závislosti Ruska na těžbě ropy a zemního plynu - budování dobrých vzájemných a nejen obchodních vztahů. Stejně se můžeme dívat na joint venture (podnik se společnou majetkovou účastí) čínské společnosti CNPC a Rosněftu: Vostok Energy Ltd., což je v historii první joint venture s ruskou firmou. Že by se Rusko v něčem přeci jen poučilo nebo je to pouhý taktický tah, jak získat kontrolu nad další energetickou oblastí? Č́na tím uspokojí svou rostoucí poptávku po energii a Rusko bude mít nový obrovský trh pro export. ${ }^{16}$

Právě proto, že př́ijmy z těžby energetických surovin spolu s daněmi tvoří půlku státních př́ijmů, chce Putin zanechat strategickou roli v této oblasti právě vládě. ${ }^{17}$ Jak moc se snaží udržet významnou roli státu $v$ těchto strategických odvětvích, můžeme vidět na př́ípadu společnosti Jukos, která byla podrobena zájmu Kremlu a pod vysokými daněmi zbankrotovala. Putin si je vědom faktu, že bez investic a lepšího managementu se obrovské zásoby nevyužijí efektivně. ${ }^{18}$ A tak hledá nové hráče a snaží se si do budoucna zajistit trvání své strategické výhody na trhu energetických surovin a už fúzí s čínskou společností či “odstraněním” té ruské soukromé.

\subsection{Ruské reformy}

Jedním z cílů, jak snížit závislost státních příjmů na těžbě fosilních paliv je přilákání nových investorů a průmyslová modernizace a $\mathrm{v}$ důsledku toho zlepšení úrovně ekonomiky. Finanční krize v roce 1998 znamenala odliv zahraničních portfoliových investic a zastavení těch př́mých. Proto vláda rok poté přijala federální zákon

13 Heinberg, R.: Energetická geopolitika 2006. Britské listy 8. 6. 2006.

14 Zrození ruské energokracie. Dostupné z http://www.europortal.cz/PrintArticle.aspx?ArtId=1354.

15 Heinberg, R.: Energetická geopolitika 2006 Britské listy 8. 6. 2006.

16 China Chemical Reporter, CNPC opens door to Russian Energy Resources, 6. 1. 2007.

17 West, J. R.: The future of Russian energy., The National Interest - Summer 2005.

18 Tamtéž. 
„O zahraničních investicích v RF“, který měl za úkol stabilizovat podmínky pro zahraniční investory, poskytovat státní garanci na zahraniční investice a svobodu repatriace zisku. Už v roce 2001 byla př́jata řada zákonů, které měly zprůhlednit daňové a legislativní podmínky, aby se Rusko stalo více perspektivnější právě z pohledu zahraničních investorů. Konkrétně to byl balík zákonů zjednodušujících registraci podniků, snížení počtu licencovaných činností a snížení počtu prověrek. Pro rozšíření prrímých zahraničních investic byl přijat Pozemkový kodex, s ním i systém účetnictví, který se plně shoduje s mezinárodními normami. Dokonce i podle výzkumů poradenské společnosti AT Kearney bylo Rusko oslovenými podnikateli zařazeno na šesté místo mezi země s vysokou investiční prŕíležitostí. ${ }^{19} \mathrm{~V}$ červenci 2005 byl přijat federální zákon o zvláštních ekonomických zónách (ZEZ), který vstoupil v platnost 1.1.2006. V těchto ZEZ budou investorům poskytované výrazné úlevy, převážně daňové. ${ }^{20} \mathrm{~V}$ následujících tabulkách můžeme vidět druh investic a jejich strukturu.

Tab. č. 1: Př́íliv zahraničních investic do Ruska, 2001-2005 (v mld. USD)

\begin{tabular}{||l|c|c|c|c|c||}
\hline \multicolumn{1}{|c|}{ Druh investic } & $\mathbf{2 0 0 1}$ & $\mathbf{2 0 0 2}$ & $\mathbf{2 0 0 3}$ & $\mathbf{2 0 0 4}$ & $\mathbf{2 0 0 5}$ I-IX \\
\hline \hline Př́mé & 3,9 & 4,0 & 6,8 & 5,6 & 6,6 \\
\hline Portfóliové & 0,6 & 0,5 & 0,4 & 0,2 & 0,4 \\
\hline Ostatní & 9,8 & 15,3 & 22,5 & 23,3 & 19,9 \\
\hline Celkem & 14,3 & 19,8 & 29,7 & 29,1 & 26,8 \\
\hline
\end{tabular}

Zdroj: Teritoriální informace - Rusko 2007.

Tabulka 2: Teritoriální struktura zahraničních investic podle zdrojových zemí (mil. USD)

\begin{tabular}{|c|c|c|c|}
\hline \multirow{2}{*}{ Země (pořadí) } & \multicolumn{2}{|c|}{ Kumulované investice ke konci 2005} & \multirow{2}{*}{$\begin{array}{c}\text { Investováno v r. } \\
2005 \\
\text { leden-září } \\
\end{array}$} \\
\hline & v mil. USD & v \% z celku & \\
\hline Celkem & 96474 & 100,0 & 26829 \\
\hline 1. Kypr & 17576 & 18,2 & 3255 \\
\hline 2. Lucembursko & 16101 & 16,7 & 3630 \\
\hline 3. Nizozemí & 15586 & 16,1 & 4055 \\
\hline 4. Velká Britanie & 9642 & 10,0 & 5003 \\
\hline 5. Německo & 9321 & 9,7 & 1388 \\
\hline 6. USA & 7157 & 7,4 & 1167 \\
\hline 7. Francie & 3483 & 3,6 & 540 \\
\hline 8. Švýcarsko & 2179 & 2,3 & 1546 \\
\hline 9. Britské panenské ostrovy & 2151 & 2,2 & 833 \\
\hline 10. Bahamské ostrovy & 1108 & 1,9 & 559 \\
\hline
\end{tabular}

Zdroj: BusinessInfo, investiční klima, Příčinou významného místa Lucemburska, Kypru a Britských panenských ostrovů mezi zahraničními investory je repatriace ruského kapitálu dříve nakumulovaného v off - shore zónách

19 Teritoriální informace - Rusko 2007, část 9.1.

20 Teritoriální informace - Rusko 2007, část 9.4.z 
Nemůžeme tedy říct, že by se Rusko nesnažilo vymanit ze své závislosti. Provedené změny, úpravy a reformy jsou toho důkazem. Více pozornosti si zaslouží reforma daňová, která nejvíce napomáhá ke snížení závislosti státní kasy na těžbě fosilních paliv.

\subsubsection{Daňová reforma ${ }^{21}$}

Tato reforma má v dlouhodobé strategii do deseti let za hlavní úkol diversifikovat ekonomiku a zdvojnásobit HDP. Způsob, jak diverzifikovat ekonomiku vidí vláda ve snížení daňového zatížení v neropném sektoru zhruba o jedno procento ročního HDP $\mathrm{v}$ príšstích letech. Naopak zvýšit chce daně v ropném sektoru a získané peníze tak budou hrát stabilizační roli. V roce 2004 byl zřízen Stabilizační fond, který je výhradně zatím používán ke splácení zahraničního dluhu, ale jeho obecný záměr je ukládat peníze získané z těžby ropy pro př́ípad, že by ceny ropy klesly, což by znamenalo značné snížení objemu státní kasy v dnešní době, kdy její závislost na těchto příjmech začíná být neúnosná. Zároveň chce vláda přehodnotit různé dotace a další neefektivnosti , zkrátka zhospodárnit veřejné výdaje.

Sjednocená sociální daň byla velmi tíživá pro malé a středně velké podniky a tak se vláda rozhodla horní hranici snížit z $36 \%$ na $26 \%$.. Stejně tak plánuje sjednotit daň z přidané hodnoty na $16 \%$. Rozhodla se zvýšit mezní míry exportních a těžebních daní $\mathrm{v}$ prŕípadě, že cena ropy z Uralu převýší 25 dolarů za barel (v účinnosti od r. 2005). Na uskutečnění reforem čeká oblast státní správy, mimo jiné i armáda, zdravotnictví a oblast vzdělávání.

Reformy $\mathrm{v}$ oblasti cen ropy jsou však zpožděné. Vláda je pověřena zvýšit cenu zemního plynu domácím obyvatelům, tedy státem dotované ceny. Zatímco je potřeba tento krok provést a posunout se tak trochu dále od závislosti státní kasy na př́ijmech z exportu ropy a plynu, mělo by být zvýšení cen pomalé, protože právě omezení růstu administrativně stanovených cen zmírňovalo inflaci. Široké strukturální reformy a snížení daňového zatížení jsou hlavními zpơsoby jak zajistit ekonomickou diversifikaci a udržitelný rozvoj.

Prezident Putin zavedl v roce 2001 rovnou daň ve výši $13 \%$. Daniel J. Mitchell z americké Heritage Foundation ve Washington Times uvedl: „My jsme sice vyhráli Studenou válku, ale Rusko se těši z rovné daně. U nás zůstává byzantský systém zdanění, který je založen na válečných potřebách. “22 Přričemž ruská rovná daň je dokonce o čtyřri procenta nižší než nejodvážnější návrhy na reforem amerického daňového systému od Steva Forbese. V tomhle článku se dokonce dočtete, že ruská státní kasa tím neutrpěla, že naopak př́ijmy federálního rozpočtu za poslední dva roky vzrostly o padesát procent jednoduše proto, že lidé vydělávají víc a bernímu úřadu to rádi přiznávají.

Nemůžeme ale nechat bez povšimnutí fakt, že mimo rovné daně, zavedl Putin i novou daň ze zisku, kterou velkým firmám snížil z 35 na $24 \%$. Menší byznysmani si mohou vybrat mezi $6 \%$ z hrubých př́ijmů či $15 \%$ ze zisku. ${ }^{23}$

Stále obrovským problémem a překážkou reforem zůstává všudypřitomná korupce.

\subsubsection{Postoje $k$ ruským reformám}

Existují různé názory na Putinovy reformy a nebude asi žádným překvapením, že v Rusku převládají ty pozitivní, zatímco jinde ty negativní. Setkáme se s názorem, že se

21 Russian Federation: 2004 Article IV Consultation - Staff Report, IMF Country Report No. 04/314.

22 Rusko v čele? V daních určitě - z 14.4. 2003.

23 Rusko v čele? V daních určitě - z 14.4. 2003. Dostupné z http://danova_svoboda.cz/indew.php?option $=$ com_content\&task=view\&id=29\&Itemid=1. 
Vladimír Putin soustředil spíše na taktickou stránku reforem, než na tu strategickou. Prezident pouze načrtává obecný směr reforem, ale jejich celkové provádění zůstává na vládě. Na strukturální reformy také čeká doposud slabý bankovní sektor, bez kterého se Rusko jen těžko zbaví závislosti na příjmech z ropy a těžko přiláká více zahraničních investorů.

Neposledním důležitým faktorem je sám postoj ruských občanů, kteří stále svou vládu vidí jako své pány a nikoliv jako své zástupce a tak čeká Rusko reforma i v myšlení svých občanů. ${ }^{24}$ Otázkou ovšem je, nakolik chce Rusko tuhle reformu uskutečnit a zda vủbec cítí její potřebu.

\section{Ropný vrchol a alternativní zdroje}

\subsection{Kdy dojde ropa ve světě?}

A proč by se vlastně Rusko mělo snažit snížit svou závislost na př́ijmech z těžby a exportu ropy a zemního plynu? V současné době se mluví o stále se přibližujícím ropném vrcholu a následující krizi. To, že ropa jednou dojde, je víc než jisté, ale kdy to bude, je už odpověd' velice se lišící. Pesimisti předpokládali, že ropa dojde už v samých začátcích, kdy se ropa začala těžit. V roce 1914 Dủlní úruad USA předpověděl, že nám zbude ropy na deset let spotřeby. V roce 1939 americké ministerstvo vnitra předpovědělo, že nám zbude ropy na třináct let spotřeby a v roce 1951 totéž. ${ }^{25}$ Ale jak se ukázalo, čím více se předpokládalo, že ropa dojde, tím spíše k tomu nedocházelo, nacházela se nová ložiska a s rostoucí cenou ropy rostla motivace vymyslet a přijít na alternativní zdroje energie. V dnešní době začínají nabývat na významu obnovitelné energetické zdroje, které zatím představují necelých $14 \%{ }^{26}$ na celkové produkci energie, ale tento podíl se i na dále bude zvyšovat a musíme mít na paměti, že když budou růst ceny ropy, bude se i zvyšovat motivace lidí přicházet na alternativy.

\subsection{Alternativní zdroje}

Uvědomme si, že technologie nestojí na místě, stále se hýbe kupředu. Stejně tak, jako doba kamenná neskončila, protože došel kámen, doba ropy neskončí proto, že dojde ropa. Až dojde ropa klasickou těžbou, jak ji známe dnes, už nebude jednoduše důležité. V rozvoji budou obnovitelné zdroje energie, které jsou prakticky nevyčerpatelné, prokázaly se nové možnosti získání ropy z živičné břidlice či energie jadernou fúzí.

Proč tady mluvím o dosažení ropného vrcholu? Chci si totiž položit otázku „co když Rusko snižuje svou závislost na těžbě ropy právě posilováním energetického trhu a získáváním tak vysokých př́imů, formováním nových (nejen obchodních) vztahů, jako je zmíněná fúze s čínskou společností?" Když se na to podíváme z vyšší perspektivy, tyto příjmy Rusko může ukládat ve větší míře do Stabilizačního fondu a do fondu investičního, který by znamenal do určité míry propojení sektoru vládního i soukromého a vytváření investičních prostředků potřebných na rozvoj nových technologií. Nové technologie a peníze na investice jsou enormně důležité, protože právě tak Rusko může rozvinout nové metody, jak např́klad získávat ropu ze živičné břidlice, či inventovat peníze do výzkumu a začít získávat energii jadernou fúzí a pak už otázka závislosti na příjmech z těžby ropy a zemního plynu klasickým způsobem bude bezpředmětná. Ovšem, zda přesně taková je

24 Reformy prezidenta Putina: Hodnocení a perspektivy, diskuse z 25.5.2005, Asociace pro mezinárodní otázky. Dostupné z www.amo.cz/cz/o_nas/diskuse.

25 Lomborg, B.: Skeptický ekolog, str. 152.

26 Lomborg, B.: Skeptický ekolog, str.161. 
politika Ruska, těžko říci. Bud' si Rusko odmítá přiznat teorii ropného vrcholu a těží ze svého postavení na energetickém trhu co nejvíce, nebo si je naopak možností vyčerpání zdrojů vědomo a právě proto buduje nové ropovody do oblasti nové vzrůstající poptávky, do Cíny, a tím se snaží vytěžit z exportu co nejvíce a získat tak potřebné investiční prostředky. Politika prezidenta Putina však není transparentní. Gazprom přerušil dočasně dodávky Ukrajině, aby si vynutil vyšší ceny a zaměstnal bývalého německého kancléře Gerharda Schrodera jako konzultanta, čímž získal většinový podíl v projektu severoevropského plynovodu. Dick Cheney obvinil ruského prezidenta, a nebojím se říct, že právem, z užití energetických zdrojů coby zbraně. ${ }^{27}$

$\mathrm{V}$ důsledku dosažení ropného vrcholu se někteří obávají z možné delegitimizace některých politických režimů a jeho projevení se v každodenním životě. ${ }^{28}$ Což se zdá být dalším logickým důvodem proč se snažit řešit závislost ruských státních př́ijmů na těžbě energetických surovin. Ale i když energii z fosilních paliv spotřebováváme stále více, zároveň nacházíme více jejích zdrojů. Dnes máme ropy na minimálně 40 let současné spotřeby, plynu na nejméně 60 let a uhlí na 230 let. Těžba živičné břidlice může při ceně 40 dolarủ za barel dodávat ropu dalších 250 let současné spotřeby. Dohromady máme tedy dost všech druhů ropy k pokrytí naší celkové spotřeby energie na příštích 5000 let. Uranu máme na dalších 14000 let. A naše současné náklady na energii představují méně než dvě procenta globálního HDP, takže i kdybychom zažili výrazné cenové vzestupy a tím stále větší závislost nejen ruské pokladny na nich, nemělo by to mít na naše bohatství žádný zásadní dopad. ${ }^{29}$ Takže tento politický argument zde jaksi postrádá svou vypovídací schopnost, i když zde mluvíme nejen o ruské produkci, ale o té světové.

\section{Závěr}

Rusko si od krize v roce 1998 výrazně zlepšilo svou ekonomickou úroveň ${ }^{30} \mathrm{z}$ větší části díky rostoucím cenám ropy a zemního plynu, ale také díky mnoha jiným faktorům. Rusko hraje prim ve vývozu a těžbě surové ropy, avšak podmínky si může určovat stále méně, právě kvůli závislosti státní kasy na př́ijmech z tohoto strategického průmyslu. Proto Rusko provádí a plánuje řadu strukturálních reforem, které ho mají vymanit z již zmíněné závislosti. Snaží se přilákat nové investice, diversifikovat ekonomii a zlepšit technologie.

Zároveň ale mějme na paměti, že s rostoucími cenami ropy a hrozbou ropného vrcholu roste motivace světa vynalézat alternativy, jejichž zárodky se už klubou na svět v podobě získávání ropy za živičné břidlice či energie jadernou fúzí.

Je důležité vzít $\mathrm{v}$ potaz i skutečnost, již několikrát zmiňovanou, že tomuto strategickému průmyslu dominují společnosti vesměs státní a politika Putina není transparentní. Mnohdy se snaží svého postavení využívat neprŕiliš š astně, jak tomu bylo v př́padě přerušení dodávek zemního plynu jeho jižním sousedům. I přes proces transformace, který $\mathrm{v}$ Rusku po rozpadu SSSR proběhl, nalezneme snadno pozůstatky minulého režimu jak v oblasti ekonomiky, tak politiky.

Pokud si tedy Rusko bude ukládat dostatečné množství peněz získaných z těžby energetických surovin do Stabilizačního fondu a nebude pouze splácet dluhy, ale především investovat do potřebných nových technologií a tím se snažit usnadnit si budoucí

27 Heinberg, R.: Energetická geopolitika 2006, Britské listy 8.6.2006.

28 Heinberg, R.: Energetická geopolitika 2006, Britské listy 8.6.2006.

29 Lomborg, B.: Skeptický ekolog,11. Energie, str. 167.

30 Viz Př́lohy Obr. 3. 
přístup k vlastním alternativním zdrojům, nebude muset řešit problémy nestability státních př́jmů. Pokud vynaloží dostatek úsilí a ochoty investovat do vědeckého výzkumu, do rozvíjení přátelských diplomatických a obchodních vztahů, může mu tato snaha v budoucnu přinést ovoce $\mathrm{v}$ podobě stejně tak výhodného postavení, jakému se těší dnes.

\section{Literatura}

[1] Teritoriální informace - Rusko 2007. Dostupné z www.businessinfo.cz.

[2] Oficiální energetické statistiky americké vlády - Energy Information Administration. Dostupné z http://www.eia.doe.gov/emeu/cabs/Russia/Background.html.

[3] LOMBORG. B.: Skeptický ekolog - Jaký je skutečný stav světa? Dokořán, Praha : Liberární Institut, 2006.

[4] HEINBERG, R.: Energetická geopolitika 2006. Britské listy, 8.6.2006.

[5] ŠIMOV, Jaroslav, KRATOCHVÍL, Petr, SVOBODA, Karel, Asociace pro mezinárodní otázky, Reformy prezidenta Putina: Hodnocení a perspektivy, diskuse z 25. 5. 2005. Dostupné z http://www.amo.cz/cz/o_nas/diskuse/historie_a_shrnuti_diskusi/index.php?ID=\&shrunti=ano\&IDdiskuse $=3 \overline{2} 0$.

[6] Rusko v čele? V daních určitě - z 14.4. 2003. Dostupné z http://danova_svoboda.cz/indew.php?option $=$ com content\&task=view\&id=29\&Itemid=1.

[7] Mezinárodní měnový fond, IMF Country Report No. 04/314, Russian Federation: 2004 Article IV Consultation - Staff Report

[8] Mezinárodní měnový fond, IMF Country Report No. 06/430, Russian Federation: Selected Issues

[9] China Chemical Reporter, článek CNPC otevírá dveře ruským energetickým zdrojům (=CNPC opens door to Russian Energy Resources) z 6.1.2007

[10] West, J.R., Budoucnost ruské energie (=The future of Russian energy), The National Interest - Summer 2005 


\section{Př́lohy}

Tab. č. 3: Struktura a index výroby a elektrické energie (mld. kWh)

\begin{tabular}{||l|c|c|c|}
\hline \hline & $\mathbf{2 0 0 3}$ & $\mathbf{2 0 0 4}$ & $\begin{array}{c}\mathbf{2 0 0 3 / 2 0 0 4} \\
\mathbf{( \% )}\end{array}$ \\
\hline \hline Výroba elektrické energie celkem & 916 & 931 & 101,6 \\
\hline 4.1.1.1.1.1 Tepelné elektrárny & 608 & 609 & 100,1 \\
\hline Vodní elektrárny & 158 & 177 & 112,2 \\
\hline Jaderné elektrárny & 150 & 145 & 96,2 \\
\hline
\end{tabular}

Zdroj: BusinessInfo.cz, Teritoriální informace - Rusko, 4.7. Infrastruktura, Energetika - Jaderná energetika, Tab. Struktura a index výroby elektrické elergie (mld. kWh), str.44

Tab. č. 4: Vybrané ekonomické indikátory, 2001 - 05 v \% HDP

\begin{tabular}{|c|c|c|c|c|c|}
\hline & 2001 & 2002 & 2003 & 2004 & 2005 \\
\hline GDP real growth rate & 5.1 & 4.7 & 7.3 & 7.2 & 6.4 \\
\hline Change in the output gap & 2.5 & 1.8 & 2.6 & 0.7 & 0.1 \\
\hline Oil price $^{1 /}$ & 23.0 & 23.5 & 27.3 & 34.3 & 49.9 \\
\hline General government balance & 2.7 & 0.6 & 1.4 & 4.9 & 8.1 \\
\hline General government primary balance & 5.4 & 2.7 & 3.3 & 6.3 & 9.2 \\
\hline Expenditure & 34.6 & 37.0 & 34.9 & 31.9 & 31.9 \\
\hline Primary expenditure & 31.9 & 34.9 & 33.0 & 30.5 & 30.8 \\
\hline Revenue & 37.3 & 37.6 & 36.3 & 36.8 & 40.0 \\
\hline Oil revenues & 6.0 & 5.7 & 6.0 & 9.2 & 14.0 \\
\hline Oil price balancing the budget & 19.0 & 22.4 & 24.1 & 20.0 & 26.0 \\
\hline General government primary non-oil balance & -0.6 & -3.1 & -2.7 & -3.0 & -4.8 \\
\hline Fiscal impulse $^{2 /}$ & 2.8 & 3.2 & 0.3 & -2.8 & -2.9 \\
\hline Non-oil fiscal impulse $\mathrm{s}^{3 /}$ & 2.1 & 3.0 & 0.6 & 0.4 & 1.8 \\
\hline
\end{tabular}

Zdroj: IMF Country Report No. 06/430, Russian Federation: Selected Issues 
Obrázek č. 1: Ropovodní a plynovodní systém

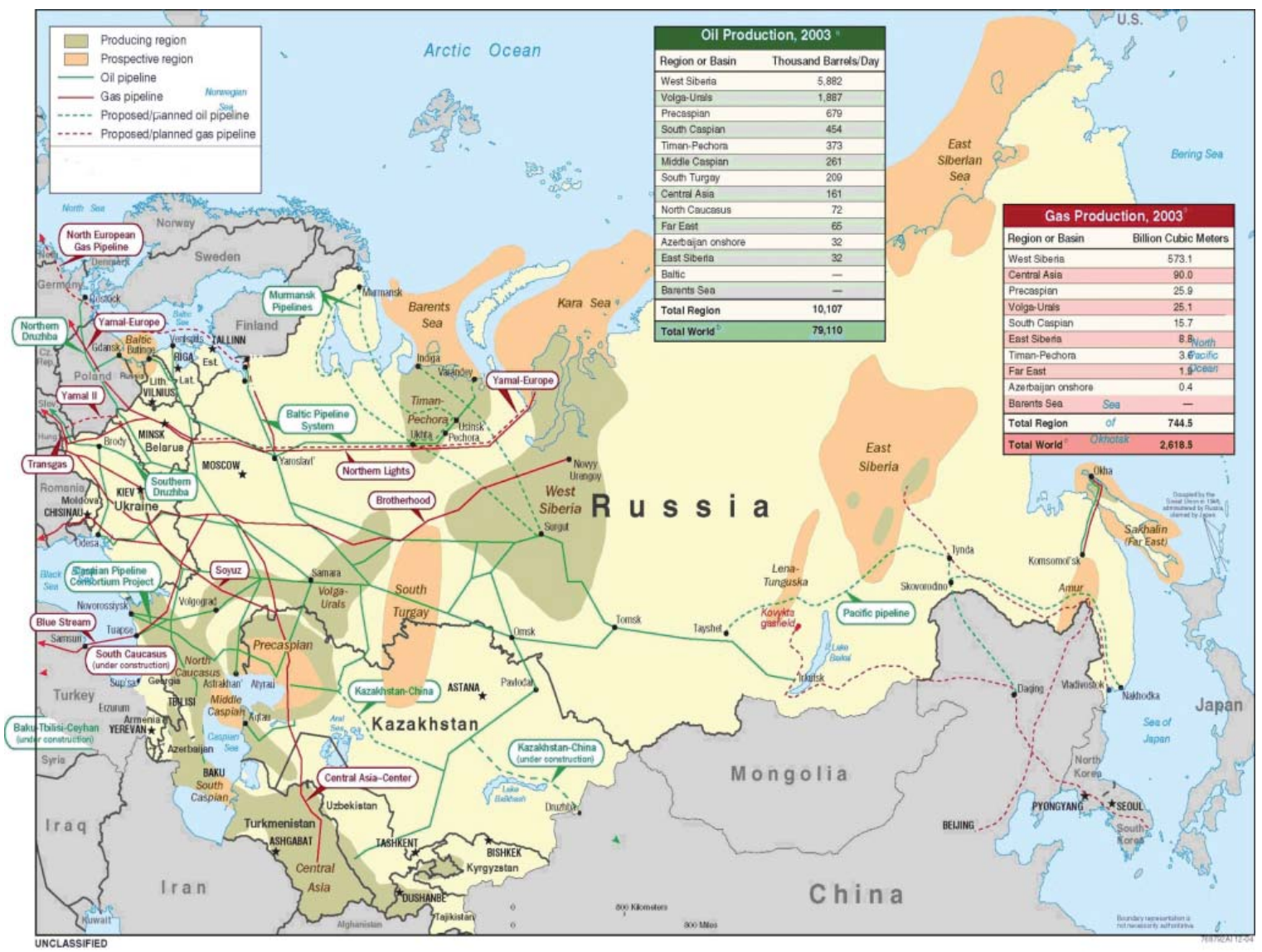

Zdroj: http://www.eia.doe.gov/emeu/cabs/Russia/Maps.html

\section{Obrázek č. 2: Hlavní obchodní toky ropy ( $v$ mil. tun )}

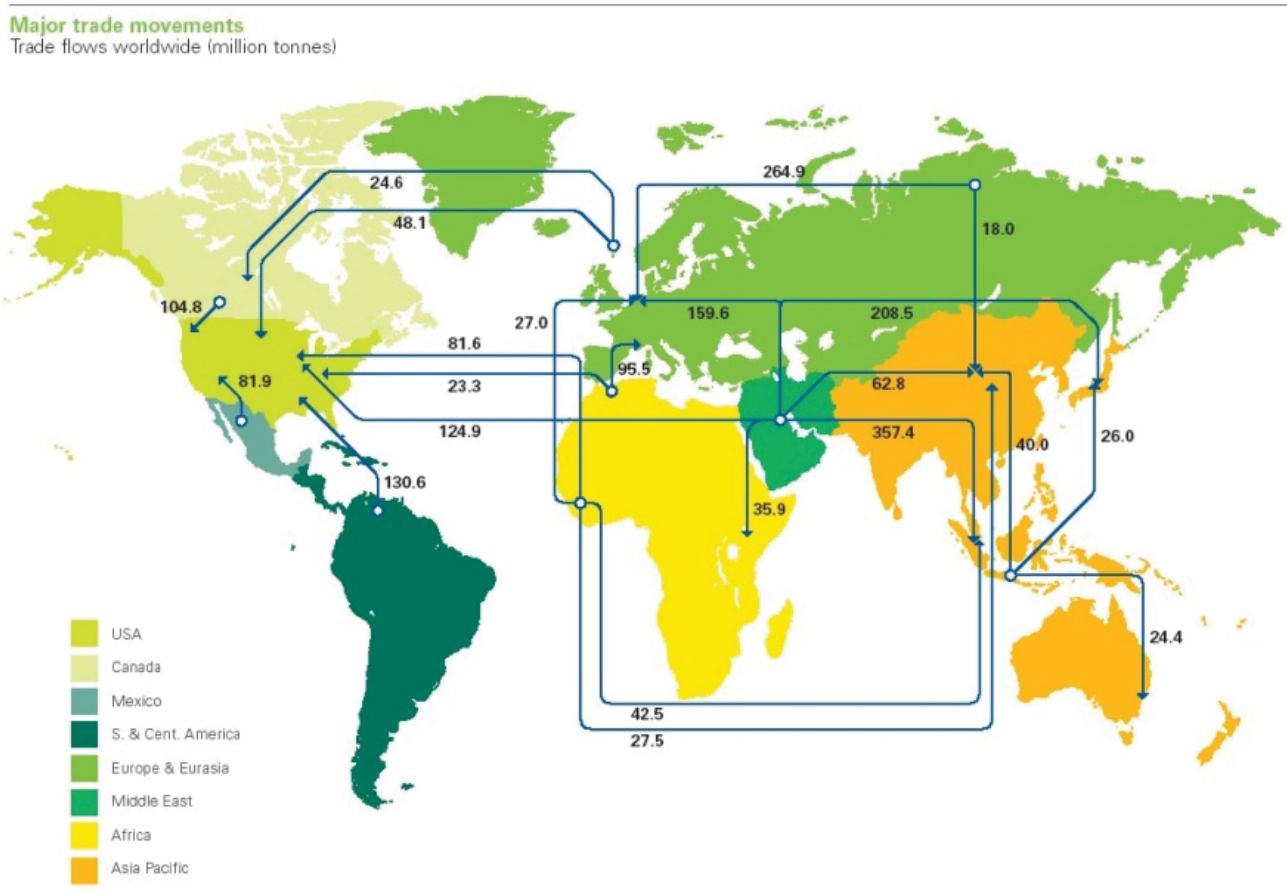

Zdroj:British Petroleum. Dostupné z www.bp.com 


\section{Obrázek č. 3: Ruská ekonomika od krize v roce $1998^{31}$}
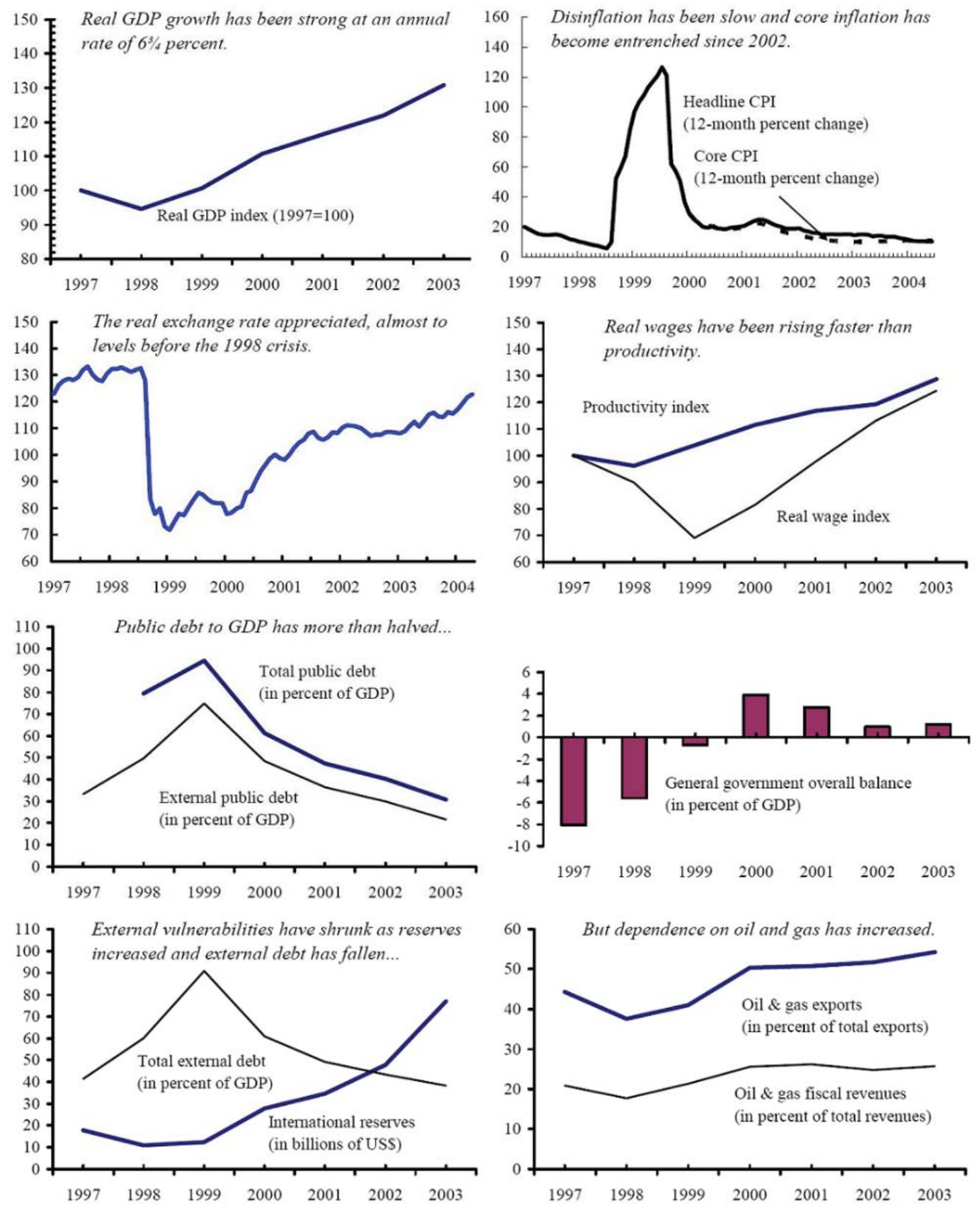

Zdroj: IMF Country Report No. 04/314, Russian Federation: 2004 Article IV Consultation - Staff Report

31 Zleva doprava: 1. graf - růst reálného HDP. 2. graf - inflace. 3. graf - reálná úroková míra. 4. graf - index produktivity (=productivity index) v poměru s indexem reálných mezd (=real wage index). 5. graf - státní dluh (=public debt) v poměru se zahraničním dluhem (=external debt) v \% HDP. 6. graf - celková vládní bilance v \% HDP. 7. graf - celkový zahraniční dluh (=total external debt) v \% HDP v poměru s mezinárodními rezervami (=international reserves) v mld.USD. 8.graf - export ropy a zemního plynu (=oil and gaz exports) v \% z celkového exportu, $\mathrm{v}$ poměru se státními př́jmy z exportu ropy a zemního plynu (=oil and gaz fikal revenues) v \% z celkových př́ijmů. 